\title{
Growth, Biomass Production and Root Development of Chinese fir in Relation to Initial Planting Density
}

\author{
Taimoor Hassan Farooq ${ }^{1,2,+}{ }^{-}$, Wenjing $\mathrm{Wu}^{1,2,+}$, Mulualem Tigabu ${ }^{1,3} \oplus^{\circ}$, Xiangqing $\mathrm{Ma}^{1,2}$, \\ Zongming $\mathrm{He}^{1,2}$, Muhammad Haroon U. Rashid ${ }^{1,2}$, Matoor Mohsin Gilani ${ }^{1,2}$ and \\ Pengfei $\mathrm{Wu}^{1,2, *}$ \\ 1 Forestry College, Fujian Agriculture and Forestry University, Fuzhou 350002, China; \\ taimoorhassan2055@gmail.com (T.H.F.); abc8526813@163.com (W.W.); mulualem.tigabu@slu.se (M.T.); \\ lxymxq@126.com (X.M.); hezongming@126.com (Z.H.); haroonrashid3838@outlook.com (M.H.U.R.); \\ matoorshah@gmail.com (M.M.G.) \\ 2 Fujian Provincial Colleges and University Engineering Research Center of Plantation Sustainable \\ Management, Fuzhou 350002, China \\ 3 Southern Swedish Forest Research Center, Faculty of Forest Science, \\ Swedish University of Agricultural Sciences, PO Box 49, SE-230 53 Alnarp, Sweden \\ * Correspondence: fjwupengfei@fafu.edu.cn; Tel.: +86-591-83780261 \\ + These authors contributed equally to this work.
}

Received: 3 January 2019; Accepted: 28 February 2019; Published: 7 March 2019

\begin{abstract}
Chinese fir (Cunninghamia lanceolata (Lamb) Hook) is a commercially valuable timber species that is widely planted in southern China and accounts for $6.1 \%$ of the global plantation forests. However, appropriate planting density that ensures high plantation productivity is largely unexplored in this species. The aim of the study was to examine tree growth, biomass production, and its allocation among different organs in relation to initial planting density, and to examine whether planting density has an impact on root development. Mortality, diameter at breast height and tree-height of all trees were determined and measured in wider $(2.36 \times 2.36 \mathrm{~m})$, intermediate $(1.83 \times 1.83 \mathrm{~m})$ and narrow $(1.44 \times 1.44 \mathrm{~m})$ spacing with stand density of 1450 trees ha ${ }^{-1}, 2460$ trees ha ${ }^{-1}$ and 3950 trees ha $^{-1}$, respectively. In each stand, three plots of $20 \times 20 \mathrm{~m}$ at a distance of $500 \mathrm{~m}$ were delineated as the sampling unit. Biomass was determined by destructive sampling of trees in each stand and developing allometric equations. Root morphological traits and their spatial distribution were also determined by carefully excavating the root systems. The results showed an increase in diameter of trees with decreasing stand density while tree height was independent of stand density. Biomass production of individual trees was significantly $(p<0.05)$ less in high-density stand $\left(32.35 \pm 2.98 \mathrm{~kg}^{-1} \mathrm{tre}^{-1}\right)$ compared to low-density stand $\left(44.72 \pm 4.96 \mathrm{~kg}\right.$ tree $\left.{ }^{-1}\right)$ and intermediate-density stand $\left(61.35 \pm 4.78 \mathrm{~kg}^{2}\right.$ tree $\left.^{-1}\right)$ while stand biomass production differed significantly in the order of intermediate $\left(67.63 \pm 5.14 \mathrm{t} \mathrm{ha}^{-1}\right)$ $>$ high $\left(57.08 \pm 3.13 \mathrm{tha}^{-1}\right)>$ low $\left(27.39 \pm 3.42 \mathrm{t} \mathrm{ha}^{-1}\right)$ stand density. Both average root length and root volume were significantly $(p<0.05)$ lower in the high-density stand than stands with low and intermediate density. Analysis of spatial distribution of root systems revealed no overlap between roots of neighboring trees in the competition zone in low-density stand, a subtle overlap in the intermediate density stand and larger overlap in the high-density stand. It can be concluded that better growth and biomass production in intermediate density stand could be explained by better root structural development coupled with minimal competition with understory vegetation and between trees; thus intermediate stand density can be optimal for sustaining long-term productivity and may reduce the management cost in the early phase of the plantation.
\end{abstract}

Keywords: allometry; Cunninghamia lanceolata; planting spacing; root morphological traits; tree competition 


\section{Introduction}

Chinese fir (Cunninghamia lanceolata (Lamb) Hook) is a typical evergreen sub-tropical conifer with high timber yield, excellent timber quality, and fast growth [1,2]. In addition to its economic importance for timber production, Chinese fir plantations provide important ecological functions, including carbon sequestration, soil and water conservation and climate regulation [3]. Chinese fir is the third most commonly planted species in plantation forests worldwide [4]. Currently, its plantations cover a total area of 11 million ha, accounting for $24 \%$ of all plantation forests in China and $6 \%$ worldwide $[5,6]$. Recently, the plantation area of Chinese fir has been enlarged to meet the increasing wood consumption accompanying the booming economy. Most plantations have been established on the same site after clear-cutting [7], resulting in a productivity decline in subsequent rotations [8]. The decline in yield and productivity is often associated with poor soil fertility under continuous planting [9-11], low photosynthetic efficiency and traditional management practices such as shorter harvesting cycles (15-17 years), successive rotations on same site and clear-cutting [12,13]. Thus, serious concerns have been raised among forest managers and researchers about the long-term productivity of Chinese fir plantations [14], particularly the influence of the harvesting practices (clear-cutting) and current short rotation regime $[14,15]$.

Planting density has significant effects on the available growing resources of each individual tree and crown characteristics, thereby affecting wood volume growth or biomass increment and wood quality [16-18]. Usually, high planting density seriously affects management due to ecological, silvicultural and economic implications [19,20]. Among trees the intensity and timing of resource competition is determined by the stand density which directly affects the tree diameter and forest productivity [21,22]. Since plant competition alters the growth and productivity, thus, understanding the relationship between stand density and biomass of particular tree components such as stem, branches, leaves, bark and roots growth would help to quantify stand development and to estimate biomass production [23-25]. There have been many studies on plant competition, e.g., [23,26-29], because it is a fundamental process affecting stand development [27]. Most previous studies focused on biomass production of C. lanceolata plantations in relation to age and provenances [30-32], while effects of planting density on growth and biomass production have not been studied. Investigation of Chinese fir stands with varying initial density was done in a simulation study mainly in connection with competition for nutrients and photosynthetic rate [12]. As biomass production is one of the components of forest ecosystem productivity [13], an understanding of the effect of initial density on biomass production is paramount to ensure sustainable production of intensively managed Chinese fir plantations.

Planting density, among others, also influences root structural development [33], with low density expected to favor better root growth than high density. Thus, initial planting density is a factor of crucial importance as it determines the extent of competition for below-ground resources [34], which in turn is reflected in the growth and biomass production of planted trees. However, there is no study available about root structural development in connection with initial planting density in Chinese fir. Improved understanding of root distribution in relation to initial planting density, will provide scientific evidence to explain the divergence in growth and biomass production associated with initial planting density of Chinese fir plantations.

The objectives of this paper were (i) to quantify and compare tree growth, biomass production and its allocation among different organs in relation to initial planting density, and (ii) to examine whether planting density has an impact on root morphological traits and their spatial distribution. We hypothesized that (1) growth and biomass production are higher for Chinese fir stand with intermediate density than low or high density due to less competition from higher understory vegetation and trees, respectively; (2) root morphological traits are higher in low and intermediate planting density than high planting density due to better growing space; and (3) root morphological traits are lower in the root zone facing competition than the root zone not facing competition with neighboring trees. 


\section{Materials and Methods}

\subsection{Study Site}

The study was carried out in Chinese fir monoculture stands (three stands per stand density level) established with varying initial density in Xinkou Experimental Forest Farm in Sanming City, Fujian Province, South China (Figure 1). The study area is located between $26^{\circ} 10^{\prime} \mathrm{N}$ and $117^{\circ} 27^{\prime} \mathrm{E}$ with an elevation range of 205 to $500 \mathrm{~m}$ above sea level. The climate is characterized as typical mid-subtropical monsoon with mean annual rainfall of $1612 \mathrm{~mm}$ and mean annual temperature of $19{ }^{\circ} \mathrm{C}$; mean monthly maximum temperature recorded was $28.8^{\circ} \mathrm{C}$ in July while mean monthly minimum was $10.4{ }^{\circ} \mathrm{C}$ in January (Figure 2). Mean annual relative humidity was $82 \%$ (data from the on-site meteorological station). The soils are acidic and classified as Silty Oxisol according to USDA soil taxonomy [35], and developed on parent sandstone. The understory vegetation was composed of herbs and shrubs (e.g., Maesa japonica Moritzi ex Zoll., Woodwardia japonica (L.f.) Sm., Callicarpa kochiana Makino, Selaginella moellendorffii Hieron., Ilex pubescens Hook. \& Arn., and Alpinia japonica Miq.). The stands were established in 2007 from seedlings after clear-cutting and burning the harvest residuals at an elevation of about $210 \mathrm{~m}$ a.s.l. The stands were established with wider spacing $(2.36 \times 2.36 \mathrm{~m}$ with stand density of 1450 trees ha $\left.{ }^{-1}\right)$, intermediate spacing $(1.83 \times 1.83 \mathrm{~m}$ with stand density of 2460 trees $\left.\mathrm{ha}^{-1}\right)$ and narrow spacing $\left(1.44 \times 1.44 \mathrm{~m}\right.$ with stand density of 3950 trees ha $\left.{ }^{-1}\right)$. Weeding was done twice in the first 3 years and then once every year thereafter.

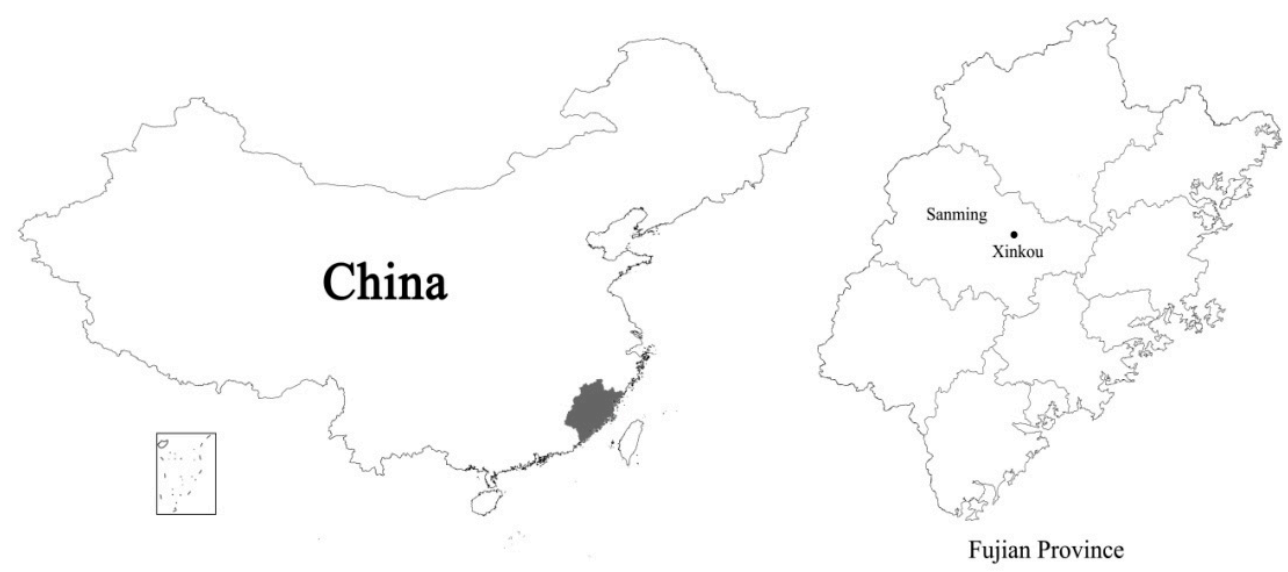

Figure 1. Location of the study area, Xinkou forest plantations, Sanming City, Fujian, China.

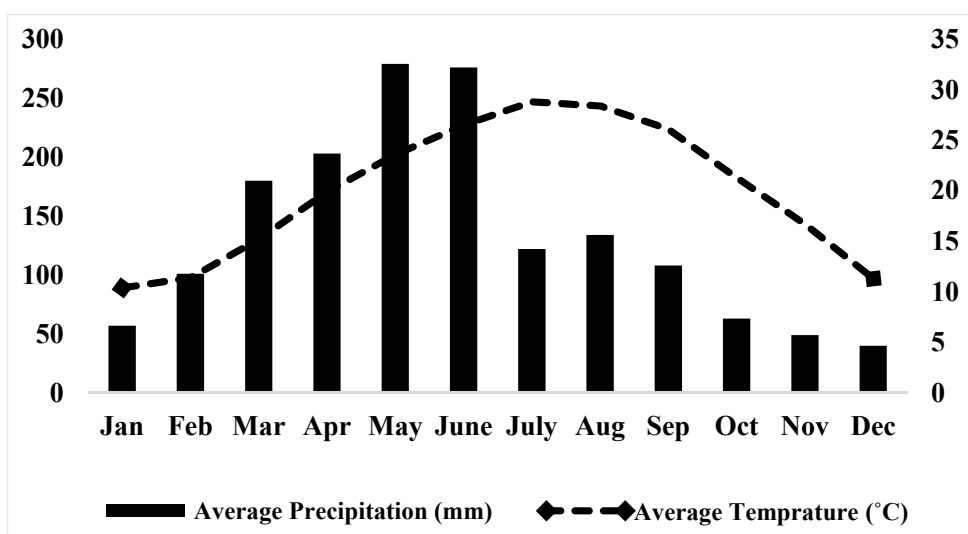

Figure 2. Average monthly precipitation and temperature of the study area in 2017.

\subsection{Determination of Biomass Production}

In each stand with a specific planting density category, three plots of $20 \times 20 \mathrm{~m}$ at a distance of $500 \mathrm{~m}$ were delineated, and diameter at breast height of trees (DBH) and total tree height growth of 
all trees were measured. Based on the average height and average diameter, six 10-year old trees per stand were selected and biomass was determined by destructive sampling and developing allometric equations. All destructive sampling was done outside but near the plot to protect the experimental plots. The sample trees were felled and branches, needles, dead needles, dead branches, and fruits were collected. The bark of each stem was stripped to determine the ratio of bark and stem wood. All roots were excavated by digging up to $100 \mathrm{~cm}$ in depth. For determining the maximum rooting depth, a combination of manual and mechanical excavation method was used. Fresh weight of all tree components (stem, branches, needles, senescence branches, senescence needles, fruits, bark and roots) was measured immediately in the field. Representative samples of all tree components were obtained for dry weight measurement. Dry weight was determined after oven-drying at $80{ }^{\circ} \mathrm{C}$ until constant weight in the lab.

\subsection{Spatial Distribution of Root Morphological Traits}

To get insights into root competition between trees, the spatial distribution of root morphological traits was examined in each stand. For this purpose, we chose two categories of trees: average tree and neighboring tree. The average tree was one that had a DBH and height equal to the average stand diameter and height, while neighboring tree was one that was nearest to the average tree but with exactly the same planting distance. For both average and neighbor trees, we chose those trees which faced competition among each other on one side while facing no or minimal competition on the other side (i.e., no trees were found on this side). In total, 18 trees ( 6 trees $\times 3$ initial densities) were carefully excavated outside the experimental plots in random plantation but close to each plot. Root samples were collected separately from both sides of trees (i.e., from sides of the trees facing each other (competition zone) and sides of the trees not facing each other (non-competition zone)) and brought to the lab at the College of Forestry, Fujian Agriculture and Forestry University. All collected roots were cleaned carefully with distilled water to remove the soil and quickly dried with filter papers. The root system was immediately scanned with the WinRhizos scanner (Regent Instruments Inc., Quebec, Canada), and total root length, total surface area, average diameter, and the average volume of roots were quantitatively analyzed. The fine $(<2 \mathrm{~mm}$ in diameter) and coarse $(>2 \mathrm{~mm}$ in diameter) roots and the stump root (the main root) biomass were also determined after oven-drying to constant weight at $80{ }^{\circ} \mathrm{C}$. Horizontal distribution of the root system was measured using a grid system. A thin and flexible wire was used to record the angle of penetration by bending it into the interior angle and then this was measured using a protractor. Drawings were mounted and photographed using a fixed camera at a fixed distance. A top view of the root system in each density was also photographed.

\subsection{Data Analysis}

Allometric equations for estimating biomass of living organs were developed by regressing the dry weight on tree height and $\mathrm{DBH}$ as follows:

$$
W_{i}=a\left(D^{2} H\right)^{b}
$$

To estimate the biomass of senescence organs the following allometric equation was used:

$$
W_{i}=a\left(D^{2} H\right)+b
$$

where $W_{i}$ is the dry weight $(\mathrm{kg})$ of a tree component (e.g., branches, needles, bark, stem wood), $H$ is the tree height $(\mathrm{m})$ of each sample tree, $D$ is $\mathrm{DBH}(\mathrm{cm})$, and $a$ and $b$ are the regression constants. To calculate the stand biomass, the estimated biomass of each organ per tree was summed up while the total stand biomass was obtained by summing each tree organ's biomass in the same plot [30].

One-way analysis of variance (ANOVA) was performed to determine overall effects of stand density on tree growth, mortality (based on counts), biomass of individual trees and at stand level as well as root morphological traits. Two-way ANOVA was performed to determine the effects of 
planting density and roots in the competition zone and those in the non-competition zone on root morphological traits. Results were declared statistically significant if $p<0.05$, and means that exhibited significant differences were compared using Tukey's significance test. All statistical analyses were performed using the SPSS Statistical Package (SPSS 17.0, Chicago, IL, USA).

\section{Results}

\subsection{Tree Growth and Biomass Production}

There were significant differences in mortality rate $(F=13.34 ; p=0.01)$ and mean diameter $(F=13.11 ; p=0.005)$ of trees in relation to initial planting density, but not for total tree height $(F=0.83$; $p=0.48$ ). The mortality rate was higher for stands with high density (annual mortality rate $=1.3 \%$ ) than stands with low ( $0.86 \%$ annual mortality rate) and intermediate density ( $1.0 \%$ annual mortality); the mean diameter of trees was higher in stands with low and intermediate density than stands with high density while the mean tree height was similar across all levels of initial stand density (Figure 3).
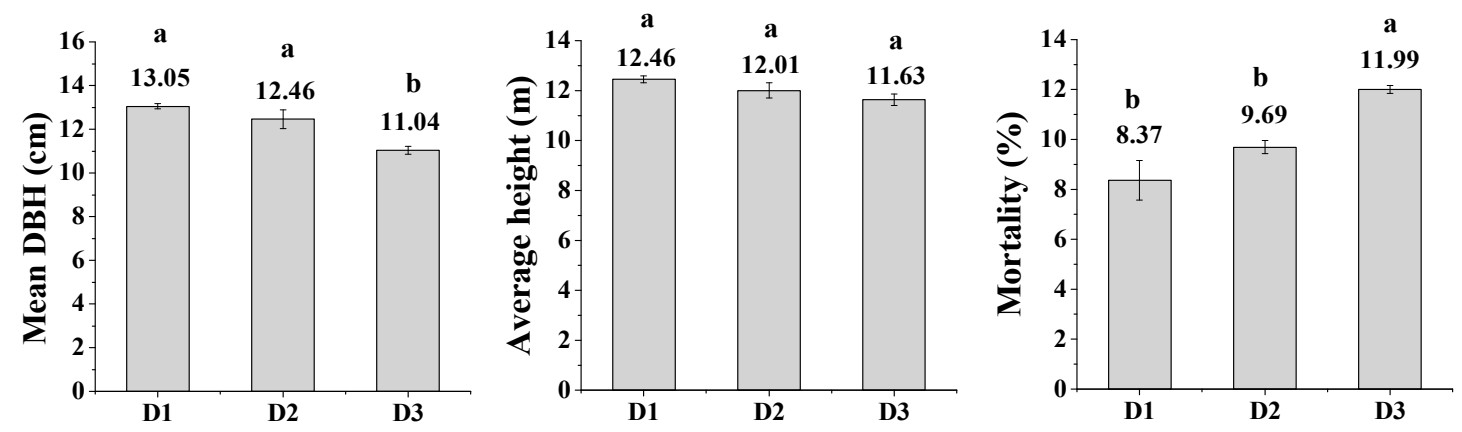

Figure 3. Mean diameter, average height and mortality (dead plants) of Chinese fir tree plantation stands with low (D1), intermediate (D2) and high (D3) initial stand density. Values are mean \pm SE, and bars with the same letter(s) for each treatment are not significantly different at the 0.05 level of probability.

The allometric equation for estimating living biomass of tree components was satisfactory with $R^{2}>0.80$ (Table 1). However, the allometric model for estimating dead organs was poor $\left(R^{2}<0.5\right.$; Table 1). Thus, the biomass of dead organs was excluded in the final estimation of above-ground biomass. The relationship between aboveground biomass and diameter at 10-11 $\mathrm{m}$ tree height revealed the stand density effect on estimated biomass (Figure 4). As a whole, the allometric model was good enough to estimate the biomass of the standing trees.

At individual tree level, there was a significant difference $(p<0.05)$ in biomass of tree components, except branch biomass and fine root biomass (Table 2). Larger biomass of needles, bark, stem, stump root and coarse roots was recorded for trees in intermediate density stand than either the low or high density stand. The above-ground biomass was the largest in intermediate density stand followed by the low density stand and the smallest being in high density stand. The below-ground biomass was larger in a stand with intermediate density than a stand with high density although intermediate density and low density stands didn't differ statistically in below-ground biomass. Stem wood represented the highest biomass of any category of tree which was $35.43 \mathrm{~kg} /$ tree $>24.84 \mathrm{~kg} /$ tree $>17.19 \mathrm{~kg} /$ tree in intermediate, low and high density stands, respectively; moreover, different organs' biomass was in the order of stem $>$ roots $>$ needles $>$ bark $>$ branches and dead branches. As a whole, the total biomass of individual trees was the largest in intermediate density stand followed by the low density stand and the smallest being for the high density stand.

At stand level, the biomass of all tree components varied significantly $(p<0.05)$ with respect to initial planting density. Total stand biomass production was higher in intermediate and low density than high density stands. In intermediate density stand, total biomass production was $67.63 \mathrm{t} \mathrm{ha}^{-1}$ while in high and low density stands it was $57.08 \mathrm{t} \mathrm{ha}^{-1}$ and $27.39 \mathrm{t} \mathrm{ha}^{-1}$, respectively. In terms of 
below-ground biomass, there was no significant difference between intermediate density and high density stands but both were significantly different to low density stand. Above-ground biomass and total biomass were also larger in stands with high and intermediate density than in a stand with low density. Stem wood represented the highest percentage of category of stand biomass, accounting for $60.1 \%, 57.7 \%$ and $53.2 \%$ in low, intermediate and high density stands, respectively. Biomass of live branches was higher in high than intermediate and low density stands. Live needles biomass was recorded in the order of $6.74 \mathrm{t} \mathrm{ha}^{-1}$ in intermediate, $5.90 \mathrm{t} \mathrm{ha}^{-1}$ in high and $2.52 \mathrm{t} \mathrm{ha}^{-1}$ in low density stands, respectively. Branch biomass was larger in stands with high density than stands with intermediate and low density, whereas biomass of other tree components was larger in stands with high and intermediate density levels than the stand with low density (Table 2).

Table 1. Allometric equations for estimating biomass of different tree components of Chinese fir planted at different initial stand density levels $(\mathrm{D}=\mathrm{DBH}, \mathrm{H}=$ height $)$.

\begin{tabular}{cccc}
\hline Stand Density & Tree Components & Biomass Equations & $\boldsymbol{R}^{2}$ \\
\hline Low & Live Branches & $W=0.0087\left(D^{2} H\right)^{0.556}$ & 0.972 \\
Live Needles & $W=0.0021\left(D^{2} H\right)^{1.324}$ & 0.911 \\
Bark & $W=0.0986\left(D^{2} H\right)^{0.425}$ & 0.836 \\
Stem & $W=0.0242\left(D^{2} H\right)^{0.983}$ & 0.879 \\
Roots & $W=0.0049\left(D^{2} H\right)^{0.793}$ & 0.982 \\
& Dead Branches & $W=0.0025\left(D^{2} H\right)-0.003$ & 0.297 \\
Dead Needles & $W=0.0004\left(D^{2} H\right)+1.552$ & 0.301 \\
Live Branches & $W=0.0652\left(D^{2} H\right)^{0.513}$ & 0.923 \\
Live Needles & $W=0.0263\left(D^{2} H\right)^{0.303}$ & 0.897 \\
Bark & $W=0.0269\left(D^{2} H\right)^{0.331}$ & 0.898 \\
Stem & $W=0.0496(D 2 H)^{0.918}$ & 0.995 \\
Roots & $W=0.0846\left(D^{2} H\right)^{0.035}$ & 0.932 \\
& Dead Branches & $W=0.0026\left(D^{2} H\right)+7.208$ & 0.347 \\
Dead Needles & $W=0.0024\left(D^{2} H\right)+6.551$ & 0.350 \\
& Live Branches & $W=0.015\left(D^{2} H\right)^{0.192}$ & 0.896 \\
& Live Needles & $W=0.019\left(D^{2} H\right)^{0.179}$ & 0.938 \\
Bark & $W=0.1442\left(D^{2} H\right)^{0.487}$ & 0.997 \\
& Stem & $W=1.4003\left(D^{2} H\right)^{0.450}$ & 0.915 \\
& Roots & $W=0.0916\left(D^{2} H\right)^{0.013}$ & 0.996 \\
& Dead Branches & $W=0.0015\left(D^{2} H\right)+0.678$ & 0.463 \\
& Dead Needles & $W=0.0009\left(D^{2} H\right)+0.384$ & 0.368 \\
\hline
\end{tabular}

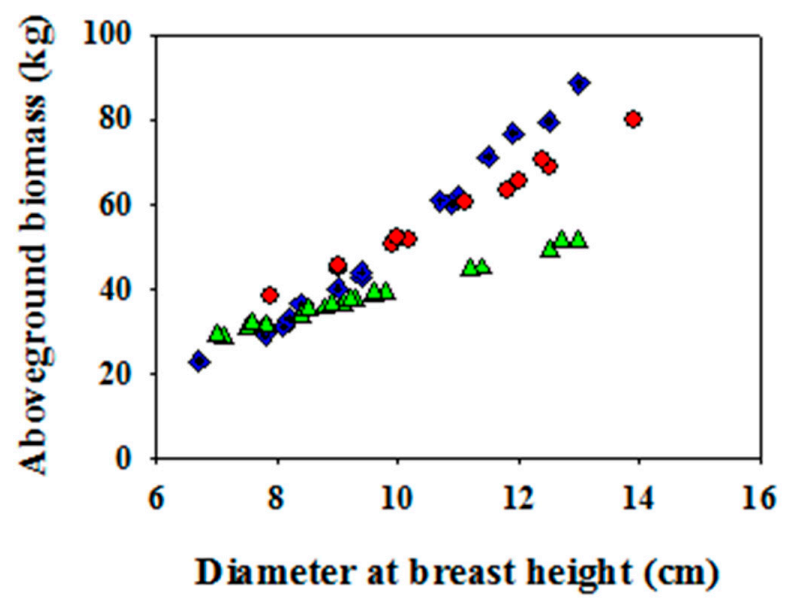

\section{- Low density}

- Intermedia te density

$\triangle \quad$ High density

Figure 4. Relationship between aboveground biomass and diameter at breast height of Chinese fir trees from different stand density levels at a specified total tree height (10-11 m). 
Table 2. Effect of initial planting density on individual tree and stand level biomass production of Chinese fir; where D1, D2 and D3 are low, intermediate and high density stands. Values are mean $\pm \mathrm{SE}$, and means followed by different letter(s) across the row are significantly different $(p<0.05)$.

\begin{tabular}{|c|c|c|c|c|c|c|}
\hline \multirow{2}{*}{ Tree Components } & \multicolumn{3}{|c|}{ Individual Tree Biomass $\left(\mathrm{kg}\right.$ tree $\left.^{-1}\right)$} & \multicolumn{3}{|c|}{ Stand Level Biomass (t ha ${ }^{-1}$ ) } \\
\hline & D1 & D2 & D3 & D1 & D2 & D3 \\
\hline Branches & $2.55 \pm 0.28 \mathrm{~A}$ & $2.59 \pm 0.30 \mathrm{~A}$ & $2.53 \pm 0.31 \mathrm{~A}$ & $1.68 \pm 0.31 \mathrm{~b}$ & $2.85 \pm 0.33 \mathrm{~b}$ & $4.47 \pm 0.56 \mathrm{a}$ \\
\hline Needles & $3.82 \pm 0.49 \mathrm{~B}$ & $6.11 \pm 0.44 \mathrm{~A}$ & $3.34 \pm 0.29 \mathrm{~B}$ & $2.52 \pm 0.46 \mathrm{~b}$ & $6.74 \pm 0.49 \mathrm{a}$ & $5.90 \pm 0.51 \mathrm{a}$ \\
\hline Dead branches & $0.76 \pm 0.22 \mathrm{AB}$ & $1.07 \pm 0.59 \mathrm{~A}$ & $0.39 \pm 0.23 \mathrm{~B}$ & $0.04 \pm 0.01 \mathrm{~b}$ & $1.34 \pm 0.32 \mathrm{a}$ & $0.94 \pm 0.19 \mathrm{a}$ \\
\hline Dead needles & $1.22 \pm 0.26 \mathrm{~B}$ & $1.89 \pm 0.31 \mathrm{~A}$ & $0.79 \pm 0.18 \mathrm{C}$ & $0.02 \pm 0.05 c$ & $1.93 \pm 0.35 \mathrm{a}$ & $1.14 \pm 0.21 b$ \\
\hline Bark & $3.15 \pm 0.25 \mathrm{AB}$ & $4.38 \pm 0.34 \mathrm{~A}$ & $2.29 \pm 0.16 \mathrm{~B}$ & $2.08 \pm 0.30 \mathrm{~b}$ & $4.83 \pm 0.38 \mathrm{a}$ & $4.05 \pm 0.28 \mathrm{a}$ \\
\hline Stem wood & $24.84 \pm 2.51 \mathrm{~B}$ & $35.43 \pm 2.32 \mathrm{~A}$ & $17.19 \pm 1.67 \mathrm{C}$ & $16.43 \pm 1.66 \mathrm{~b}$ & $39.05 \pm 2.66 \mathrm{a}$ & $30.32 \pm 1.19 a$ \\
\hline Total agb * & $36.34 \pm 3.75 \mathrm{~B}$ & $51.48 \pm 3.99 \mathrm{~A}$ & $26.53 \pm 2.66 \mathrm{C}$ & $22.73 \pm 2.74 b$ & $56.74 \pm 4.51 \mathrm{a}$ & $46.82 \pm 2.94$ \\
\hline Stump root & $6.78 \pm 1.0 \mathrm{AB}$ & $8.19 \pm 0.61 \mathrm{~A}$ & $5.10 \pm 0.22 \mathrm{~B}$ & $7.48 \pm 0.66 b$ & $9.03 \pm 0.21 \mathrm{a}$ & $8.99 \pm 0.39 a$ \\
\hline Coarse root & $1.38 \pm 0.19 \mathrm{~A}$ & $1.47 \pm 0.23 \mathrm{~A}$ & $0.57 \pm 0.08 \mathrm{~B}$ & $0.03 \pm 0.01 \mathrm{~b}$ & $1.63 \pm 0.37 \mathrm{a}$ & $1.01 \pm 0.15 a$ \\
\hline Fine root & $0.22 \pm 0.02 \mathrm{~A}$ & $0.21 \pm 0.04 \mathrm{~A}$ & $0.15 \pm 0.02 \mathrm{~A}$ & $0.15 \pm 0.01 \mathrm{~b}$ & $0.23 \pm 0.05 a$ & $0.26 \pm 0.04 \mathrm{a}$ \\
\hline Total bgb ** & $8.38 \pm 1.21 \mathrm{AB}$ & $9.87 \pm 0.88 \mathrm{~A}$ & $5.82 \pm 0.31 \mathrm{~B}$ & $7.66 \pm 0.68 b$ & $10.89 \pm 0.63 a$ & $10.26 \pm 0.19$ \\
\hline Total biomass & $44.72 \pm 4.96 \mathrm{~B}$ & $61.35 \pm 4.78 \mathrm{~A}$ & $32.35 \pm 2.98 \mathrm{C}$ & $27.39 \pm 3.42 b$ & $67.63 \pm 4.14 \mathrm{a}$ & $57.08 \pm 3.13 a$ \\
\hline
\end{tabular}

${ }^{*} \mathrm{agb}=$ above ground biomass; ${ }^{* *} \mathrm{bgb}=$ Below ground biomass. 


\subsection{Root Morphological Traits and Their Spatial Distribution}

Among examined root morphological traits, significant differences were detected in average root length $(F=4.55 ; p=0.012)$, root surface area $(F=9.66 ; p=0.010)$, mean root diameter $(F=4.51 ; p=0.013)$ and root volume $(F=8.15 ; p=0.001)$ with respect to initial planting density. The average root length significantly decreased with increasing stand density while root surface area was significantly higher in intermediate density compared to high density stand but similar with low density stand. Mean root diameter was significantly higher in intermediate density stand than low and high density while root volume was significantly higher in stands with intermediate density than stands with high density but similar with low density stand (Figure 5).
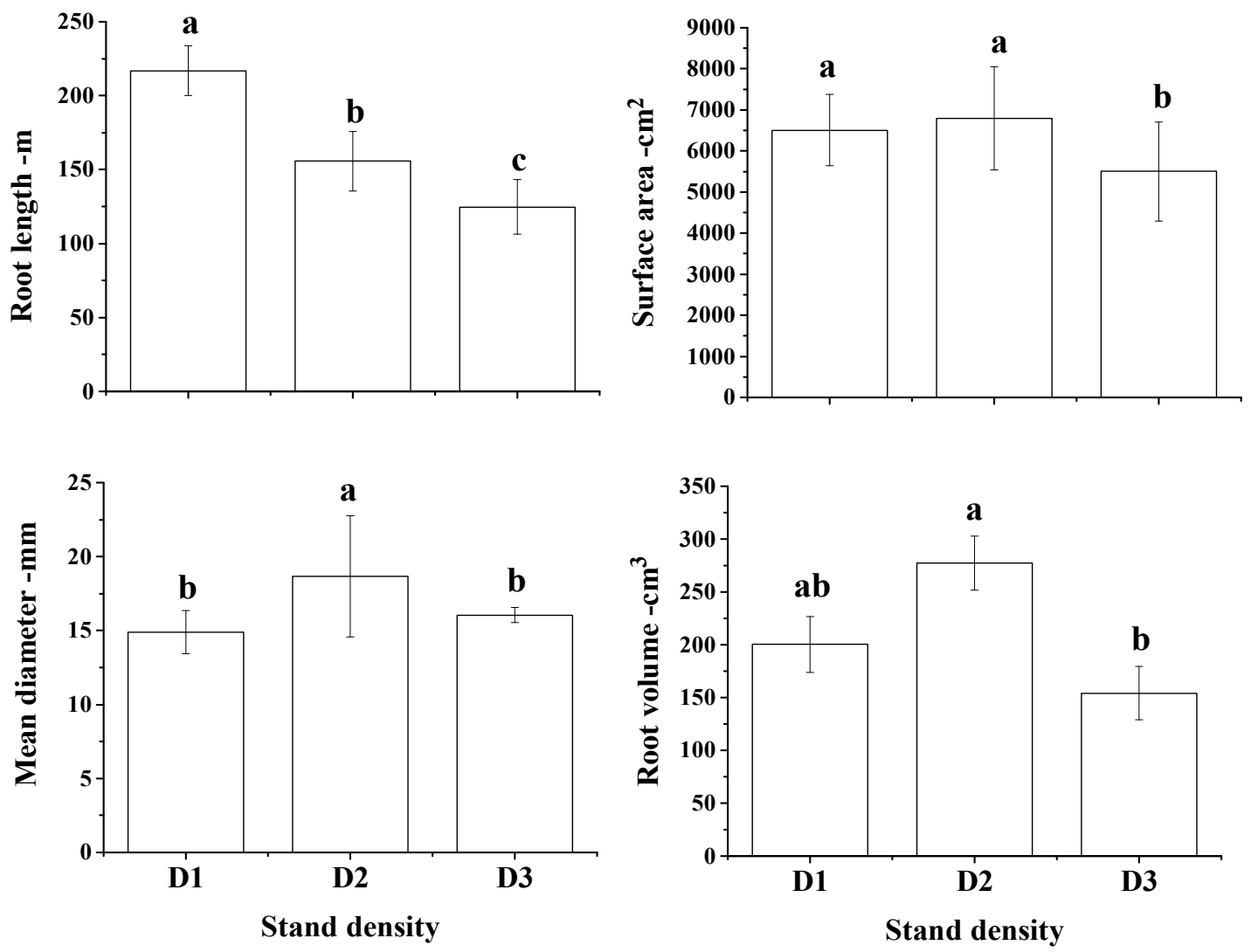

Figure 5. Root morphological traits of Chinese fir trees planted in low (D1), intermediate (D2) and high (D3) initial stand density. Values are mean $\pm \mathrm{SE}$, and bars with the same letter(s) for each treatment are not significantly different at the 0.05 level of probability.

With regard to spatial distribution of root morphological traits, significant differences were detected in average root length ( $p=0.026$ for planting density and $p=0.004$ for root zones) and average root surface area ( $p=0.023$ for planting density and $p=0.015$ for root zones) among levels of planting density and root zones of average and neighboring trees. Significant differences were also detected in average root volume $(p=0.038)$ and coarse root biomass $(p=0.04)$ with respect to planting density only. Neither average root diameter nor fine root biomass showed significant differences. There were no significant interaction effects of planting density and root zones. Average root length, root surface area, root volume, and coarse root biomass were lower in the high density stand than in intermediate density stand, however, the low and intermediate density stands had similar values (Figure 6). 

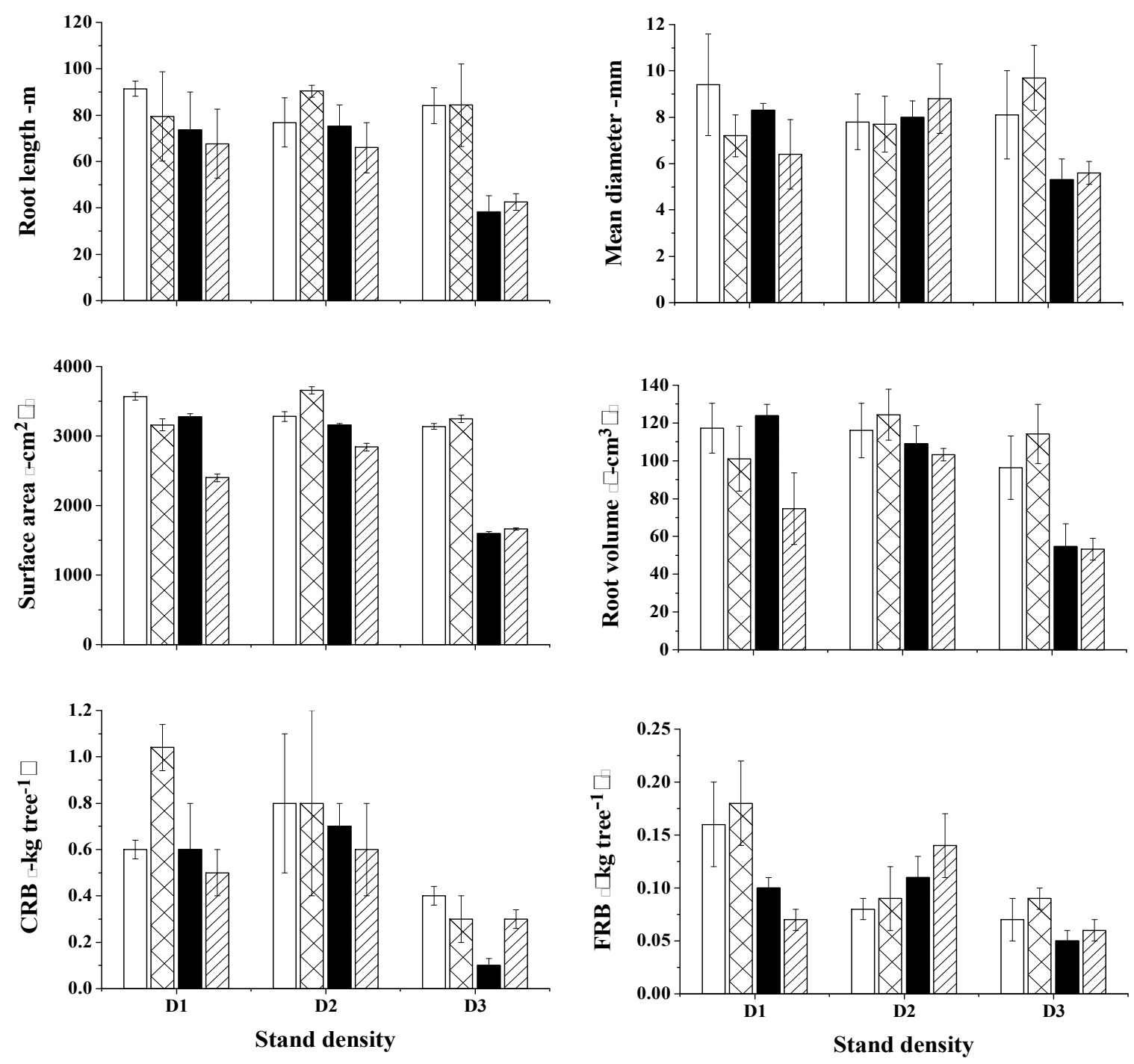

\section{AT-FC $\triangle \triangle$ AT-WOC $\square$ NT-FC $Z / 7 \triangle$ NT-WOC}

Figure 6. Distribution of root morphological traits of average and neighboring trees in competition and non-competition zones in the studied Chinese fir plantation. AT-FC and AT-WOC represent part of the root system of average trees (AT) in competition (FC) and non-competition (WOC) zones, respectively, and NT-FC and NT-WOC represent part of the root system of neighboring trees (NT) in competition and non-competition zones, respectively. CRB and FRB stand for coarse root biomass and fine root biomass, respectively.

The average root length was significantly lower for the root of neighboring trees in competition zone and non-competition zones than for roots of average trees in both competition and non-competition zones. Root surface area was larger for roots of average trees irrespective of the root zone than roots of neighboring trees that didn't face competition whereas root surface area was statistically similar between roots of average trees and neighboring trees in the competition zone. The top view of the root structure also depicted no overlap between roots of average and neighboring trees in the competition zone in low density stand, a subtle overlap in the intermediate density stand and larger overlap in the high density stand (Figure 7). 


\section{Average tree - Neighboring tree}
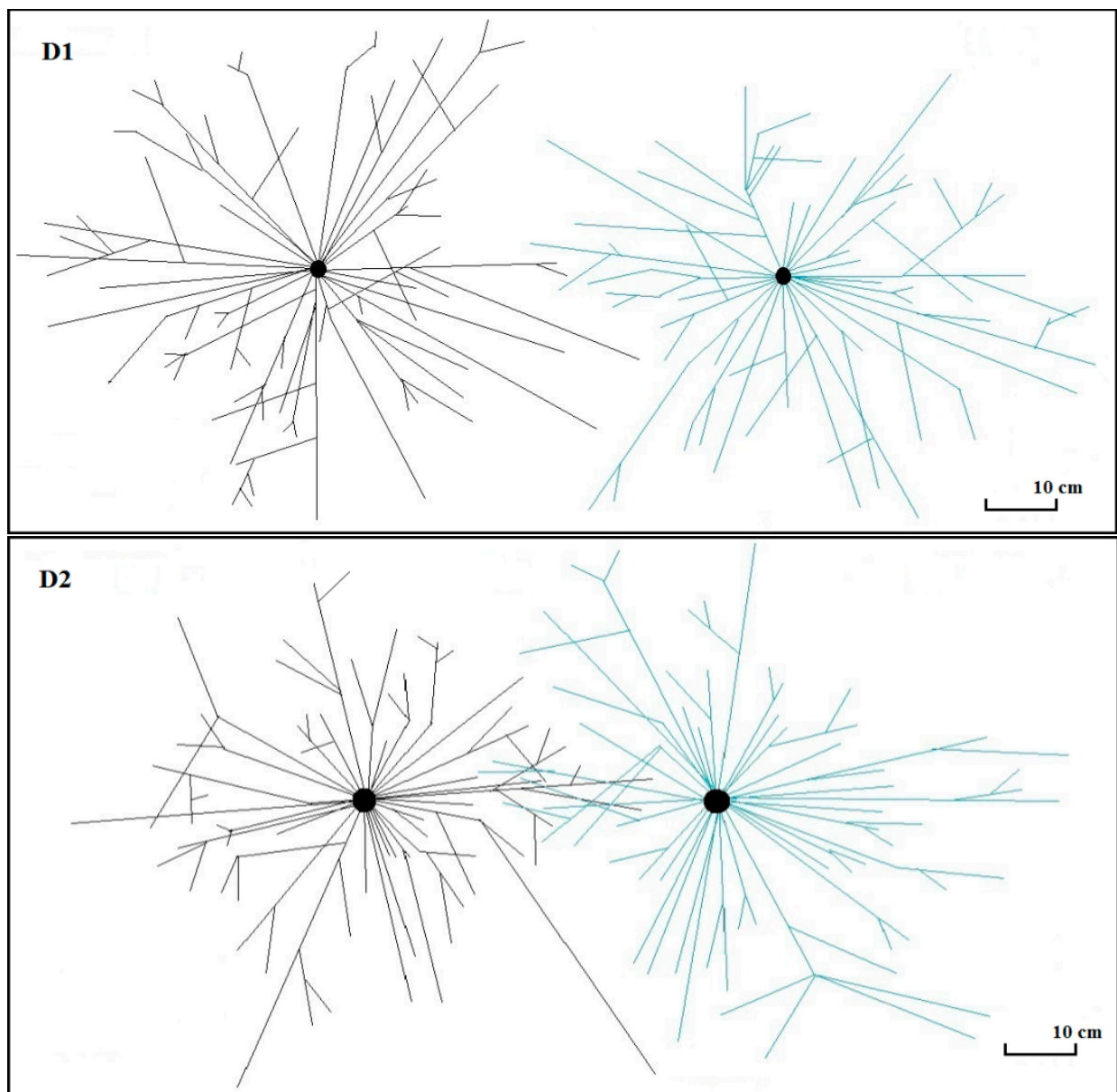

D3

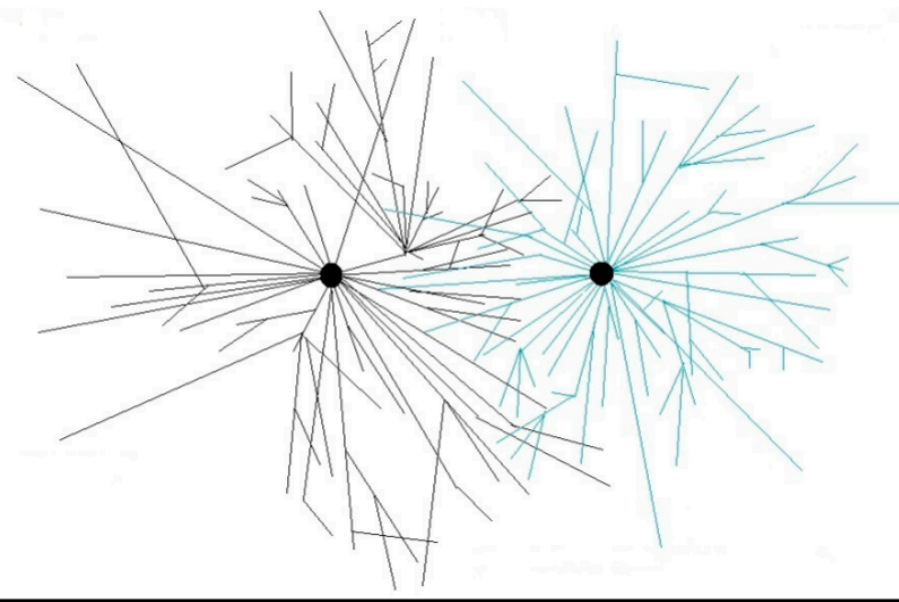

Figure 7. Top view of the root structure of average tree and neighboring tree in low (D1), intermediate (D2) and high stand density (D3) configurations of Chinese fir.

\section{Discussion}

In any plantation program, the choice of appropriate planting density and genotype is an important first step as these determine management practices and cost during planting and in the early phase after planting [36,37]. Tree growth is generally a function of age, tree spacing, and site quality. Particularly, planting density plays a vital role in the growth of trees and also influences the function and structure of the forest ecosystem [38]. In this study, planting density influenced the tree 
diameter (DBH) and mortality rate but not tree height (Figure 3). Tree mortality occurred in all stands; however, it was higher in the high density stand as high density often leads to a relatively long period of severe competition. This can be explained by the fact that increasing number of trees in high density stand exploits the same amount of below-ground available resources (nutrients and water) by a higher number of trees than in low-density stand [39]. The mortality in intermediate and low-density stands was most likely due to storms as the dead trees were snapped. Density-dependent mortality begins when tree competition becomes more intense, which can decrease plant density [23].

The DBH in this study showed a significant response to initial planting spacing, and DBH decreased with increased planting density, in line with previous studies [16,40,41] where high initial planting density slowed the $\mathrm{DBH}$ growth. In a study by [23], a reduction in stem $\mathrm{DBH}$ with increasing stand density in Eucalyptus urophylla stands was established. Our study is also consistent with other stand density experiments on DBH decrease, for instance in E. pellita and E. camaldulensis plantations [42], E. nitens plantation [43], and E. pilularis and E. cloeziana plantations [44]. The decreased tree growth with high planting density can be due to competition over growing resources such as light, water and nutrients [44-47], which in turn affects crown size, synthesis of carbohydrates and hormonal growth regulators [12].

The effect of stand density on height growth of Chinese fir stands was, however, not as noticeable as the effect on DBH, which is in line with other studies $[16,46,48]$. The relationship between plant height and density differs with site, tree species and stand growth. Few studies reported that tree height is insensitive to planting density in young stands $[49,50]$, while some studies mentioned that plant height increases with increasing stand density [51-53], moreover, some reported greater height growth in intermediate density compared to low and high densities [54,55]. Our results provide credence to the hypothesis that tree height growth remains unaffected by increasing planting density within a certain range of planting density but might be significantly modified by site quality and genotype [56].

Stem volume is a function of tree diameter and height, hence these are important indicators of tree biomass [56]. The results in the present study showed that initial planting density had a significant effect on biomass production of Chinese fir plantations at individual tree and stand levels (Table 2). At individual tree level, tree biomass was larger in intermediate density stand as compared to low and high density stands. While competition between trees accounted for biomass reduction in high density stand, competition with understory vegetation would be the likely cause of biomass reduction in the low density stand. We observed an abundant growth of shrubs and herbs in the understory of low density stand compared to the other stands during the inventory. In poplar plantations, a high diversity of understory vegetation was also observed in wider planting density [16]. At plantation stand level, biomass production increases with increasing stand density due to the biomass of the extra trees compensating for the decrease in the size of individuals [57]. Stem wood biomass, which contributes much to the total biomass, was higher in intermediate density stand than low density stands, which is consistent with other studies $[41,58,59]$. Reduction in the stem wood of individual trees in high density can be explained by the fact that decreasing growing space can intensify the competition for water and nutrients, which could significantly affect the stem wood and large branches biomass. Biomass of live branches and needles was higher in the high density stand than low density stand in contrast to previous findings [43] which stated that when the spacing between trees decreased the branch and foliage biomass decreases to compensate for the stem wood. The discrepancies might be related to the type of species studied; i.e., broadleaved versus coniferous species; and the response could be species-specific.

Initial planting density strongly affects the root development; particularly average root length and root volume were significantly higher in low and intermediate density stands than high density stands (Figure 5). Root morphological traits are drastically affected by tree density as root length increased and spread evenly in low density stands due to the large growth space [60] and minimal competition for growing space [61]. This can be further evidenced in the present study from the spatial 
distribution of root morphological traits of average and neighboring trees (Figure 6) and the top view of the root development of the average tree and the competing tree where there was a large overlap of roots in the competition zone (Figure 7). The distribution of roots differed in the soil in different planting spacing [62] and it has a direct effect on the plant's ability to extract nutrients and water from the soil [63]. As individual trees grow, competition for below-ground resources is more intense in high density stand than in the low and intermediate density stands, thus the roots among individual trees overlap with each other which in turn affects tree growth more than in the low density stand [64]. In wider plantation, the roots deeply penetrate into the soil because of more growth space while in narrow spacing they seem to penetrate into shallow soil surface for the root-available resources [65]. Our results are consistent with previous studies, which demonstrated that root length and root biomass increases as planting density decreases $[66,67]$. In our study, the average root diameter is independent of tree density and spacing, which is in line with a previous study that demonstrated that average root diameter is insensitive to stand density [68]. This might be a trade-off between carbon cost and increased production of bigger and longer roots. Consequently, the plant must allocate resources either to produce bigger or longer roots for optimal nutrient uptake. As a whole, better growth and biomass production in intermediate density stand could be attributed to better root structural development coupled with the minimal competition with understory vegetation and between trees compared to low and high density stands, respectively.

\section{Conclusions}

The study assessed the variation in growth, biomass production and root development in relation to initial planting density of Chinese fir plantations. The diameter of trees was significantly higher in stands with low and intermediate density than stands with high density. Biomass production of individual trees was significantly higher in stands with intermediate density than in stands with low or high density. Stand Biomass production generally increased with increasing stand density but tended to be higher in stands with intermediate density. With regard to root morphological traits, average root length and root volume were significantly higher in stands with low and intermediate density, respectively. The spatial distribution of the root system suggests lack of or minimal competition between trees in stands with low and intermediate density. This result will assist in justifying recommendations on stand density for maximum production, but further research on silvicultural management techniques and economic analysis is needed to verify the strategies which are more appropriate for the intensive management of Chinese fir plantations.

Author Contributions: T.H.F. and P.W. conceived the idea; T.H.F., Z.H., X.M. and P.W. designed the study. T.H.F., M.H.U.R., M.M.G. and W.W. performed the field and lab work, T.H.F. and M.T. analyzed the data, and T.H.F., W.W., M.T., X.M. and P.W. discussed the results, revised, and edited the manuscript.

Funding: This research was financially supported by National Natural Science Foundation of China (31870614 and 31370531) and the Science and Technology Major Project of Fujian Province, China (2018NZ0001-1).

Acknowledgments: We would also like to thank Zhen Yang, Xu Jingjing, Wang Nemin and Yan Yao for their help in conducting fieldwork.

Conflicts of Interest: The authors declare no conflict of interest.

\section{References}

1. Wu, Z.L. Chinese Fir; Forestry of China Publications: Beijing, China, 1984.

2. Yu, X. Silviculture of Chinese-Fir; Science and Technology Press of Fujian: Fuzhou, China, 1997.

3. Yao, L.; Kang, W.; Zhao, Z.; He, J. Carbon fixed characteristics of plant of Chinese fir (Cunninghamia lanceolata) plantation at different growth stages in Huitong. Acta Ecol. Sin. 2015, 35, 1-16.

4. FAO. State of the World's Forests; Food and Agriculture Organization of the United Nations: Rome, Italy, 2007; pp. 88-90.

5. SFA (State Forestry Administration of Forest Resources Management). The 7 th national forest resources inventory and the status of forest resources. For. Resour. Manag. 2010, 1, 1-8. 
6. FAO. Global Forest Resources Assessment. Rome 2015. Available online: http://www.fao.org/forestresources-assessment/en/ (accessed on 20 December 2018).

7. Ma, X.; Liu, C.; Hannu, I.; Westman, C.J.; Liu, A. Biomass, litterfall and the nutrient fluxes in Chinese fir stands of different age in subtropical China. J. For. Res. 2002, 13, 165-170. [CrossRef]

8. Ma, X. Advance in researches on productivity decline of replanting Chinese-fir forests. J. Fujian For. Coll. 2001, 21, 380-384.

9. Ding, Y.; Tian, Y.; Qi, L. A testing simulation with FORECAST on long-term productivity of Chinese-fir plantations. For. Stud. China 1999, 1, 34-38.

10. Wu, P.; Wang, G.; Farooq, T.H.; Li, Q.; Zou, X.; Ma, X. Low phosphorus and competition affect Chinese fir cutting growth and root organic acid content: Does neighboring root activity aggravate P nutrient deficiency? J. Soils Sediments 2017, 17, 2775-2785. [CrossRef]

11. Yang, Y.; Cheng, G.; Huang, B. Variation in soil water and nutrients between different rotation stands of Chinese fir. J. Nanjing For. Univ. 2000, 24, 25-28.

12. Dong, T.; Zhang, Y.; Zhang, Y.; Zhang, S. Continuous planting under a high density enhances the competition for nutrients among young Cunninghamia lanceolata saplings. Ann. For. Sci. 2015, 73, 331-339. [CrossRef]

13. Tian, D. A long-term evaluation of biomass production in first and second rotations of Chinese fir plantations at the same site. Forestry 2011, 84, 411-418. [CrossRef]

14. Zhao, M.; Xiang, W.; Tian, D.; Deng, X.; Huang, Z.; Zhou, X.; Peng, C. Effects of increased nitrogen deposition and rotation length on long-term productivity of Cunninghamia lanceolata plantation in southern China. PLoS ONE 2013, 8, e55376. [CrossRef] [PubMed]

15. Ma, X.; Heal, K.V.; Liu, A.; Jarvis, P.G. Nutrient cycling and distribution in different-aged plantations of Chinese fir in southern China. For. Ecol. Manag. 2007, 243, 61-74. [CrossRef]

16. Tun, T.N.; Guo, J.; Fang, S.; Tian, Y. Planting spacing affects canopy structure, biomass production and stem roundness in poplar plantations. Scand. J. For. Res. 2018, 33, 464-474. [CrossRef]

17. Liziniewicz, M.; Ekö, P.M.; Agestam, E. Effect of spacing on 23-year-old lodgepole pine (Pinus contorta Dougl. var. latifolia) in southern Sweden. Scand. J. For. Res. 2010, 27, 361-371. [CrossRef]

18. Nagar, B.; Rawat, S.; Rathiesh, P.; Sekar, I. Impact of initial spacing on growth and yield of Eucalyptus camaldulensis in arid region of India. World Appl. Sci. J. 2015, 33, 1362-1368.

19. Ciancio, O.; Garfi, V.; Marziliano, P.A.; Menguzzato, G.; Pelle, L. Effects of plant ing densitiy on douglas fir stands. Ital. J. For. Mt. Environ. 2008, 59, 519-534.

20. La Marca, O.; Marziliano, P.A.; Moretti, N. Experimental research in ageing holm oak (Quercus ilex L.) coppices: Preliminary results. Ann. For. Sci. 1998, 4, 461-476. [CrossRef]

21. Harrington, T.B.; Harrington, C.A.; DeBell, D.S. Effects of planting spacing and site quality on 25 -year growth and mortality relationships of Douglas-fir (Pseudotsuga menziesiivar.menziesii). For. Ecol. Manag. 2009, 258, 18-25. [CrossRef]

22. Zeide, B. How to measure stand density. Trees 2005, 19, 1-14. [CrossRef]

23. Xue, L.; Pan, L.; Zhang, R.; Xu, P.B. Density effects on the growth of self-thinning Eucalyptus urophylla stands. Trees 2011, 25, 1021-1031. [CrossRef]

24. Sprintsin, M.; Karnieli, A.; Sprintsin, S.; Cohen, S.; Berliner, P. Relationships between stand density and canopy structure in a dryland forest as estimated by ground-based measurements and multi-spectral spaceborne images. J. Arid Environ. 2009, 73, 955-962. [CrossRef]

25. Weiner, J. Asymmetric competition in plant populations. Tree 1990, 5, 360-364. [CrossRef]

26. Manning, P.; Houston, K.; Evans, T. Shifts in seed size across experimental nitrogen enrichment and plant density gradients. Basic Appl. Ecol. 2009, 10, 300-308. [CrossRef]

27. Berger, U.; Piou, C.; Schiffers, K.; Grimm, V. Competition among plants: Concepts, individual-based modeling approaches, and a proposal for a future research strategy. Perspect. Plant Ecol. Evol. Syst. 2008, 9, 121-135. [CrossRef]

28. Hunt, M.A.; Battaglia, M.; Davidson, N.J.; Unwin, G.L. Competition between plantation Eucalyptus nitens and Acacia dealbata weeds in northeastern Tasmania. For. Ecol. Manag. 2006, 233, 260-274. [CrossRef]

29. Fetene, M. Intra- and inter-specific competition between seedlings of Acacia etbaicaand a perennial grass (Hyparrenia hirta). J. Arid Environ. 2003, 55, 441-451. [CrossRef] 
30. Zhou, L.; Shalom, A.-D.D.; Wu, P.; He, Z.; Liu, C.; Ma, X. Biomass production, nutrient cycling and distribution in age-sequence Chinese fir (Cunninghamia lanceolata) plantations in subtropical China. J. For. Res. 2016, 27, 357-368. [CrossRef]

31. Zhao, M.; Zhou, G.-S. Estimation of biomass and net primary productivity of major planted forests in China based on forest inventory data. For. Ecol. Manag. 2005, 207, 295-313. [CrossRef]

32. Wu, P.; Tigabu, M.; Ma, X.; Odén, P.C.; He, Y.; Yu, X.; He, Z. Variations in biomass, nutrient contents and nutrient use efficiency among Chinese fir provenances. Silvae Genet. 2011, 60, 95-105. [CrossRef]

33. Atkinson, C.; Webster, A. The influence of the development of temperate fruit tree species on the potential for their uptake of radionuclides. J. Environ. Radioact. 2001, 52, 131-146. [CrossRef]

34. Marziliano, P.A.; Coletta, V.; Menguzzato, G.; Nicolaci, A.; Pellicone, G.; Veltri, A. Effects of planting density on the distribution of biomass in a douglas-fir plantation in southern Italy. Iforest 2015, 8, 368. [CrossRef]

35. USDA Soil Survey Staff. Soil Taxonomy; Agriculture Handbook 436; USDA: Washington, DC, USA, 1999.

36. Sanesi, G.; Lafortezza, R.; Marziliano, P.A.; Ragazzi, A.; Mariani, L. Assessing the current status of urban forest resources in the context of Parco Nord, Milan, Italy. Landsc. Ecol. Eng. 2007, 3, 187-198. [CrossRef]

37. Corona, P.; Marziliano, P.A.; Scotti, R. Top-down growth modelling: A prototype for poplar plantations in Italy. For. Ecol. Manag. 2002, 161, 65-73. [CrossRef]

38. Nissen, T.; Midmore, D.; Keeler, A. Biophysical and economic tradeoffs of intercropping timber with food crops in the Philippine uplands. Agric. Syst. 2001, 67, 49-69. [CrossRef]

39. Aref, I.; El-Juhany, L.; Nasroon, T. Pattern of above-ground biomass production and allocation in Leucaena leucocephala trees when planted at different spacing. Saudi J. Biol. Sci. 1999, 6, 27-34.

40. McEvoy, T.J. Positive Impact Forestry: A Sustainable Approach to Managing Woodlands; Island Press: Washington, DC, USA, 2012; pp. 1-268.

41. Cardoso, D.J.; Lacerda, A.E.B.; Rosot, M.A.D.; Garrastazú, M.C.; Lima, R.T. Influence of spacing regimes on the development of loblolly pine (Pinus taeda L.) in Southern Brazil. For. Ecol. Manag. 2013, 310, 761-769. [CrossRef]

42. Bernardo, A.L.; Reis, M.G.F.; Reis, G.G.; Harrison, R.B.; Firme, D.J. Effect of spacing on growth and biomass distribution in Eucalyptus camaldulensis, E. pellitaand E. urophylla plantations in southeastern Brazil. For. Ecol. Manag. 1998, 104, 1-13. [CrossRef]

43. Pinkard, E.; Neilsen, W. Crown and stand characteristics of Eucalyptus nitens in response to initial spacing: Implications for thinning. For. Ecol. Manag. 2003, 172, 215-227. [CrossRef]

44. Alcorn, P.J.; Pyttel, P.; Bauhus, J.; Smith, R.G.B.; Thomas, D.; James, R.; Nicotra, A. Effects of initial planting density on branch development in 4-year-old plantation grown Eucalyptus pilularis and Eucalyptus cloeziana trees. For. Ecol. Manag. 2007, 252, 41-51. [CrossRef]

45. Wang, C. Effect of planting density on knot attributes and branch occlusion of Betula alnoides under natural pruning in southern China. Forests 2015, 6, 1343-1361. [CrossRef]

46. Neilsen, W.A.; Gerrand, A.M. Growth and branching habit of Eucalyptus nitens at different spacing and the effect on final crop selection. For. Ecol. Manag. 1999, 123, 217-229. [CrossRef]

47. Kearney, D. Characterisation of Branching Patterns, Changes Caused by Variations in Initial Stocking and Implications for Silviculture, for E. grandis and E. pilularis Plantations in the North Coast Region of NSW. Honours Thesis, Department of Forestry, The Australian National University, Canberra, Australia, 1999; p. 89.

48. Khan, G.; Chaudhry, A.K. Effect of spacing and plant density on the growth of poplar (Populus deltoides) trees under agro-forestry system. Pak. J. Agric. Sci. 2007, 44, 321-327.

49. Lanner, R.M. On the insensitivity of height growth to spacing. For. Ecol. Manag. 1985, 13, 143-148. [CrossRef]

50. Seidel, K.W. A Western Larch-Engelmann Spruce Spacing Study in Eastern Oregon: Results after 10 Years; USDA For Serv Res Note PNW-409; US Department of Agriculture, Forest Service, Pacific Northwest Research Station: Portland, OR, USA, 1984.

51. Ritchie, G.A. Evidence for red: Far red signaling and photomorphogenic response in Douglas-fir (Pseudotsuga menziesii) seedlings. Tree Physiol. 1997, 17, 161-168. [CrossRef] [PubMed]

52. Knowe, S.A.; Hibbs, D.E. Stand structure of young red alder as affected by plant density. For. Ecol. Manag. 1996, 82, 69-85. [CrossRef] 
53. Gilbert, I.R.; Seavers, G.P.; Jarvis, P.G.; Smith, H. Photomorphogenesis and canopy dynamics. Phytochrome-mediated proximity perception accounts for the growth dynamics of canopies of Populus trichocarpa $\times$ deltoids 'Beaupre'. Plant Cell Environ. 1995, 18, 475-497. [CrossRef]

54. Giordano, P.A.; Hibbs, D.E. Morphological response to competition in red alder: The role of water. Funct. Ecol. 1993, 7, 462-468. [CrossRef]

55. Pienaar, L.V.; Shiver, B.D. Early results from an old-field loblolly pine spacing study in the Georgia Piedmont with competition control. South J. Appl. For. 1993, 17, 193-196.

56. Toillon, J.; Fichot, R.; Dallé, E.; Berthelot, A.; Brignolas, F.; Marron, N. Planting density affects growth and water-use efficiency depending on site in Populus deltoides $\times$ P. nigra. For. Ecol. Manag. 2013, 304, 345-354. [CrossRef]

57. Dickens, E.D.; Barnett, J.P.; Hubbard, W.G.; Jokela, E.J. Slash Pine: Still Growing and Growing!; Gen. Tech. Rep. SRS-76; USDA Forest Service, Southern Research Station: Asheville, NC, USA, 2004; p. 148.

58. Zhang, J.; Ritchie, M.W.; Maguire, D.A.; Oliver, W.W. Thinning ponderosa pine (Pinus ponderosa) stands reduces mortality while maintaining stand productivity. Can. J. For. Res. 2013, 43, 311-320. [CrossRef]

59. Newton, P.; Jolliffe, P. Aboveground modular component responses to intraspecific competition within density-stressed black spruce stands. Can. J. For. Res. 1998, 28, 1587-1610. [CrossRef]

60. Stokes, A.; Atger, C.; Bengough, A.G.; Fourcaud, T.; Sidle, R.C. Desirable plant root traits for protecting natural and engineered slopes against landslides. Plant Soil 2009, 324, 1-30. [CrossRef]

61. Mandal, K.; Hati, K.; Misra, A.; Bandyopadhyay, K. Root biomass, crop response and water-yield relationship of mustard (Brassica juncea L.) grown under combinations of irrigation and nutrient application. Irrig. Sci. 2010, 28, 271-280. [CrossRef]

62. Douglas, G.B.; McIvor, I.R.; Potter, J.F.; Foote, L.G. Root distribution of poplar at varying densities on pastoral hill country. Plant Soil 2010, 333, 147-161. [CrossRef]

63. Liu, L.; Gan, Y.; Bueckert, R.; Van Rees, K. Rooting systems of oilseed and pulse crops. II: Vertical distribution patterns across the soil profile. Field Crops Res. 2010, 122, 248-255. [CrossRef]

64. Loades, K.W.; Bengough, A.G.; Bransby, M.F.; Hallett, P.D. Planting density influence on fibrous root reinforcement of soils. Ecol. Eng. 2010, 36, 276-284. [CrossRef]

65. Van Noordwijk, M.; Lawson, G.; Hairiah, K.; Wilson, J. Root Distribution of Trees and Crops: Competition and/or Complementarity Tree-Crop Interactions: Agroforestry in a Changing Climate; CABI: Wallingford, UK, 2015; pp. 221-257.

66. Litton, C.M.; Ryan, M.G.; Tinker, D.B.; Knight, D.H. Belowground and aboveground biomass in young postfire lodgepole pine forests of contrasting tree density. Can. J. For. Res. 2003, 33, 351-363. [CrossRef]

67. Chang, R.; Fu, B.; Liu, G.; Yao, X.; Wang, S. Effects of soil physicochemical properties and stand age on fine root biomass and vertical distribution of plantation forests in the Loess Plateau of China. Ecol. Res. 2012, 27, 827-836. [CrossRef]

68. McIvor, I.; Douglas, G.; Hurst, S.; Hussain, Z.; Foote, A. Structural root growth of young Veronese poplars on erodible slopes in the southern North Island, New Zealand. Agrofor. Syst. 2008, 72, 75-86. [CrossRef]

(C) 2019 by the authors. Licensee MDPI, Basel, Switzerland. This article is an open access article distributed under the terms and conditions of the Creative Commons Attribution (CC BY) license (http:// creativecommons.org/licenses/by/4.0/). 